\title{
Effect of coat colour on heat stress among West African Dwarf sheep
}

A O. Sanusi, S. O. Peters, A. O. Sonibare and M. O Ozojie

Department of Animal Breeding and Genetics,

Abstract

University of Agriculture, P.M.B. 2240, Abeokuta

This experiment was conducted to investigate the effect of coat colour on heat stress among West African Dwarf sheep. A total number of twenty-four West African Dwarf sheep with different coat colour types were used for the experiment. Rectal temperature (RT), respiratory rate $(\mathrm{RR})$ and pulse rate $(\mathrm{PR})$ were taken on each animal before sunrise and when they returned from grazing in the afternoon during late dry season ( January-March) and early rainy season (April June ). Blood samples were collected for evaluation of packed cell volume (PCV), red blood cell count (RBC), white blood cell count (WBC), plasma sodium $\left(\mathrm{Na}^{+}\right)$and potassium $\left(\mathrm{K}^{+}\right)$. Coat colour had significant $(\mathrm{P}<0.01)$ effect on $\mathrm{PT}, \mathrm{RR}, \mathrm{PR}$ and heat stress index (HI). Animals with black coat colour (aaB-SS) had the highest mean value for all parameters followed by brown mouflon and brown with extensive white, while the badger face coloured sheep(A-B-ss) had the least mean value. There were significant $(\mathrm{P}<0.01)$ differences between males and female in RT $\left(38.69 \pm 0.02\right.$ and $\left.38.83 \pm 0.02^{\circ} \mathrm{C}\right), \mathrm{RR}(56.09 \pm$ 0.58 and $59.94 \pm 0.65$ breaths/min), PR (74.67 \pm 0.39 and $77.92 \pm 0.46$ beats $/ \mathrm{min})$ and HI $(1.60 \pm 00.19$ and $1.63 \pm 0.02)$ respectively. Season had significant $(\mathrm{P}<0.01)$ effect on $\mathrm{RT}, \mathrm{RR}$, $\mathrm{PR}, \mathrm{HI}$. Coat colour also had significant $(\mathrm{P}<0.05)$ effect on $\mathrm{RBC}, \mathrm{WBC}, \mathrm{Na}^{+}$and $\mathrm{K}^{+}$. There were appreciable difference between female and male in $\mathrm{RBC}, \mathrm{WBC}, \mathrm{Na}^{+}$and $\mathrm{K}^{+}$. Seasonal variation also significantly affected these blood parameters. However, PCV was not significantly $(\mathrm{P}>0.05)$ affected by variation in coat colour, sex and season. From the results obtained, it can be concluded that coat colour type had significant effect on heat stress in West African Dwarf sheep.

Key Words: Coat colour, heat stress, sheep, rectal temperature, respiratory rate, pulse

\section{Introduction:}

The ability of an animal to maintain homeostasis under heat stress is a valuable trait in the sub tropical and tropical region. Altan et al. (2003) reported that environments of high temperature and humility are detrimental to the productivity of livestock. Silanikove (2000) reported that the best physiological parameter to objectively monitor animal welfare in hot environment is the rectal temperature. Neurons that are temperature sensitive are located throughout the animal's body and send information to the hypothalamus, which invokes numerous physiological anatomic or behavioral changes in the attempt to maintain to maintain heat balance. When the physiological mechanism of animal fail to negate the excessive heat load, the rectal temperature increases. Such exposure of animal to heat stress evokes a series of drastic changes in the biological functions, which include a decrease in feed intake, disturbances in water, protein, energy and mineral balances, enzymatic reactions, hormonal secretions and blood metabolism ( Marai et al., 2003; Gwatibaya et al ., 2007).

According to Srikandakumar (2003), heat stress increases rectal temperature and respiratory rate in Omani and Merino sheep but Omani sheep is more tolerate than Merino sheep in Australia. The study carried out by Butswat et al. (2000) to investigate the heat tolerance of Yankasa, Uda and Balami breeds of sheep showed 
that there were significant differences between Yankasa and the other breeds $\{U d a$ and Balami $\}$ in rectal temperature, respiratory rate, and pulse rate.

Apart from breed differences, there is the need to study qualitative trait as possible indicators of genetic superiority or production adaptability. These qualitative traits include coat type and colour presence or absence of wattle, horn, beard, supernumerary teats and so on .Coat colour in sheep varied widely, ranging from black, brown to white and combination of these colours in various proportion. Coat colour inheritance and goats is majorly controlled by alleles in three loci (A,B and S), although genes on the extension locus act as modifier genes ( Ozoje, 1998). Coat colour is highly repeatable character and with high heritability estimate (Adalsteinsson et al., 1994).There is a need to determine the genetic superiority of different coat colour of West Africa sheep with regards to heat stress as this is the predominant breed of sheep in the humid tropics of Nigeria where high relative humidity do exacerbates the effects of high temperature .The present study was undertaken to determine the effects of coats colour on the physiological and haematological indicators of heat stress in West African Dwarf sheep.

\section{Materials and Methods}

The experiment was carried out at the sheep unit of the College of Animal Science and Livestock Production Research Farm, University of Agriculture Alabata, Abeokuta ,Ogun state, Nigeria. Alabata $\left(7^{0} 10^{\prime}\right.$ and $3^{\circ} 2^{\prime}$ E) is in Odeda Local government area of Ogun State, Nigeria. Twenty-four West Africa Dwarf sheep with different coat colours were used for the experiment.
The coat colour types were black (aaBSS), brown with extensive white markings (aabbss), brown mouflon (Aabbss), (dorsal part is pigmented with brown while the belly is white), badger face (A-B-ss) (belly and face are pigmented while the dorsal part is white) and black with extensive white markings (aaB-ss). They were sourced from villages and markets in Ogun and Oyo states, Nigeria. The animals were

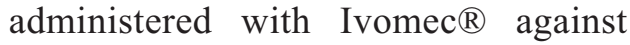
endoparasite ,ectoparasite and skin infection at a dosage of $0.05 \mathrm{ml} / \mathrm{kg}$, and also treated with Oxytetracyclin LA ${ }^{\circledR}$ (a broad spectrum antibiotics) at a dosage of $0.2 \mathrm{mg} / \mathrm{kg}$ and vaccinated with Peste des petits ruminant vaccine(PPRV) during the quarantine period. Semi intensive management system was practiced. The animals were allowed to graze in the morning and this was supplemented with concentrate feed in the afternoon. Clean water was provided for the animals throughout the period of the experiment. The animals were periodically washed (dipped) with prectosol ${ }^{\circledR}$ against ticks and other ectoparasites during the period of the experiment. The health of the animals was properly monitored and immediate adequate treatment was given to unhealthy animals.

\section{Collection of physiological data}

Rectal temperature, pulse rate and respiratory rate off all the animal was measured early in the morning between $7.00 \mathrm{am}$ and $8.00 \mathrm{am}$ before the rising of sun. The animals were then exposed to heat from solar radiation during the grazing period till $1.00 \mathrm{pm}$. The rectal temperature, respiratory rate and pulse were measured again between $1.00 \mathrm{pm}$ and $2.00 \mathrm{pm}$. Data was collected three times a week for twenty weeks in late dry season and early raining season. 
Rectal Temperature: This was taken on each animal using a digital thermometer. The sensory tip was disinfected and inserted into the rectum at the display of $\mathrm{L}$ ${ }^{\circ} \mathrm{C}$ by the thermometer (which indicated that the thermometer is set for temperature reading). This was removed after the sound of the alarm signal. The displayed body temperature was then recorded.

Respiratory rate: This was determined by counting the number of flank movements per minute

Pulse rate: This was determined for each animal by placing the fingertips on the femoral arteries of the hind limb for one minute.

\section{Collection and analysis of blood samples}

Blood sample were collected during late dry season (January March) and early raining season (April June). About 4$5 \mathrm{ml}$ of blood sample were collected by Jugular venipuncture from each animal, $2 \mathrm{ml}$ of which was dispensed into clean bottle containing Ethylene Diamine Tetra Acetic acid (EDTA) as an anti-coagulant and labeled. The rest were allowed to clot and also labeled accordingly. The packed cell volume (PCV), red blood cell (RBC), white blood cell (WBC) count, plasma sodium and potassium were determined. All the parameters were determined according to the method described by Edington and Gilles (1981)

\section{Statistical Analysis:}

Data obtained from the physiological indices measurement were analyzed using the Generalized linear Model (GLM) of SAS (2005) software package. The linear model is as specified below:

$$
\begin{aligned}
& \text { Yijkl }=\mu+\mathrm{A}_{\mathrm{c}}+\mathrm{B}_{\mathrm{s}}+\mathrm{P}_{\mathrm{p}}+(\mathrm{AB})_{\mathrm{cs}}+(\mathrm{AP}) \\
& { }_{\mathrm{cp}}+(\mathrm{BP})_{\mathrm{sp}}+(\mathrm{ABP})_{\mathrm{csp}}+\mathrm{e}_{\mathrm{cspr}}
\end{aligned}
$$

Yijk $=$ the parameter of interest

$\mu=$ overall mean for the parameter of interest

$A_{c}=$ fixed effect of ith coat colour $(c=1-5)$

$\mathrm{B}_{\mathrm{s}}=$ fixed effect of $\mathrm{jth} \operatorname{sex}(\mathrm{s}=1-2)$

$P_{p}=$ fixed effect of kth season $(p=1-2)$

$(\mathrm{AB})_{\mathrm{cs}}=$ interaction effect of ith coat colour and jth sex

$(\mathrm{AP})_{\mathrm{cp}}=$ interaction effect of $\mathrm{jth}$ coat colour and kth season

$(B P)_{s p}=$ interaction effect of jth sex and kth season

$(\mathrm{ABP})_{\mathrm{csp}}=$ interaction effect of coat colour, sex and season

$\mathrm{e}_{\text {cspr }}=$ random error associated with each record ( normally, independently and identically distributed with zero mean and constant variance

Significantly means were separated using the Duncan Multiple range test procedure of the same statistical software.

Heat stress index $(\mathrm{HI})$

The relationship between pulse rate and respiratory rate together with their normal average values were used to derive heat stress index. Data obtained from the analysis of blood sample were also analyzed using SAS 2005 and the same model stated above.

\section{Result and Discussion}

Physiological parameters:

Coat colour had significant effect $(\mathrm{P}<0.01)$ on the physiological parameters studied.

The least square means for all the physiological parameters as affected by coat colour are presented in Table 1.

On rectal temperature, observation ranged from $38.58 \pm 0.03^{\circ} \mathrm{C}$. Animal with black coat (aaB-SS) had the 
Table 1: Least square means for physiological parameters as influenced by coat colour, season and sex

\begin{tabular}{|c|c|c|c|c|c|c|c|c|}
\hline Coat colour & Rectal temp( & $\left.{ }^{\circ} \mathrm{C}\right)$ & \multicolumn{2}{|c|}{$\begin{array}{l}\text { Respiratory } \\
\text { rate(breaths/min) }\end{array}$} & \multicolumn{2}{|l|}{$\begin{array}{l}\text { Pulse rate } \\
\text { (beats/min) }\end{array}$} & \multicolumn{2}{|l|}{$\begin{array}{l}\text { Heat stress } \\
\text { Index }\end{array}$} \\
\hline Black(aaB -SS) & $38.92 \pm 0.03$ & a & $65.09 \pm 1.06$ & a & $81.35 \pm 0.78$ & a & $1.70 \pm 0.01$ & a \\
\hline $\begin{array}{l}\text { B row n } \\
\text { extensive } \\
\text { white(aabbss) }\end{array}$ & $38.77 \pm 0.03$ & $\mathrm{~b}$ & $58.08 \pm 1.18$ & bc & $75.60 \pm 0.77$ & $\mathrm{~b}$ & $1.66 \pm .00$ & $\mathrm{~b}$ \\
\hline $\begin{array}{l}\text { Brown mouflon } \\
\text { (Aabb ss) }\end{array}$ & $38.62 \pm 0.03$ & $\mathrm{c}$ & $55.58 \pm 1.08$ & $\mathrm{c}$ & $73.41 \pm 0.68$ & c & $1.64 \pm 0.01$ & $\mathrm{c}$ \\
\hline $\begin{array}{l}\text { Badger face } \\
\text { (A - B -ss) }\end{array}$ & $38.58 \pm 0.02$ & $\mathrm{c}$ & $51.31 \pm 0.65$ & d & $73.23 \pm 0.47$ & $\mathrm{c}$ & $1.48 \pm .01$ & d \\
\hline $\begin{array}{l}\text { Black with } \\
\text { extensive white } \\
\text { (aaB -ss) }\end{array}$ & $38.85 \pm 0.02$ & a & $58.82 \pm 0.84$ & $\mathrm{~b}$ & $76.09 \pm 0.58$ & $\mathrm{~b}$ & $1.65 \pm .01$ & bc \\
\hline \multicolumn{9}{|l|}{ Season } \\
\hline Late dry season & $38.93 \pm 0.01$ & a & $65.17 \pm 0.63$ & a & $80.86 \pm 0.50$ & a & $1.64 \pm .02$ & $\mathrm{a}$ \\
\hline $\begin{array}{l}\text { Early rainy } \\
\text { season }\end{array}$ & $38.60 \pm 0.02$ & b & $50.87 \pm 0.54$ & b & $71.73 \pm 0.30$ & b & $1.59 \pm .17$ & b \\
\hline \multicolumn{9}{|l|}{ Sex } \\
\hline Female & $38.83 \pm 0.02$ & a & $59.94 \pm 0.65$ & a & $77.92 \pm 0.46$ & a & $1.63 \pm 0.02$ & $\mathrm{a}$ \\
\hline Male & $38.69 \pm 0.02$ & b & $56.09 \pm 0.58$ & b & $74.67 \pm 0.39$ & b & $1.60 \pm .19$ & b \\
\hline
\end{tabular}

highest means value, while badger face coloured sheep (A-B-ss) had the least value. Rectal temperature was very high for black coat (aaB-SS) as result of the absorption of solar radiation by the dark pigmentation. The light pigmentation of the dorsal part of badger faced sheep reflects more solar radiation and absorbs less solar radiation into the body. This result was in agreement with the report of Hansen (2004) who reported that light coloured hair coats and hair coats that are sleek and shiny reflects a greater proportion of incident solar radiation than hair coats that are dark in colour or more dense or wooly as well as the report of Chytil (2002) that slick haired sheep which are able to reflect more solar radiation had lower respiratory rate, sweating rate and rectal temperature than normal haired sheep during the hot season in Florida.

The observed result with respiratory rate was significantly $(\mathrm{P}<0.01)$ affected by coat colour. It followed the same pattern observed with rectal temperature. Badger face (A-B-ss) had the least value of $51.31 \pm 0.065$ breaths $/ \mathrm{min}$ while black had the highest value of $65.09 \pm 1.06$ breaths/min. Black animals had the highest respiratory rate. The animals panted in order to increase body cooling by respiratory evaporation since the major evaporatory heat loss mechanism is panting. Coat colour also significantly $(\mathrm{P}<0.01)$ affected pulse rate. The pulse rate observed ranged from $73.23 \pm 0.47$ beats $/ \mathrm{min}$ to $81.35 \pm 0.78$ beats $/ \mathrm{min}$. The highest pulse rat was recorded for black coat (aaB-Ss). Coat colour also had significant effect on heat stress index. Heat stress index ranged from $1.48 \pm 0.01$ 
to $1.70 \pm 0.01$ with the average value of 1.62. Black coat (aaB-SS) also had the highest estimated value while badger face had the least value as shown in Table 1.

The result showed that the effect of sex of sheep significantly affected the physiological parameters studied $(\mathrm{P}<0.01)$. The rectal temperature for female $\left(38.69 \pm 0.02^{\circ} \mathrm{C}\right)$ was significantly higher than that observed among males $\left(38.69 \pm 0.02^{\circ} \mathrm{C}\right)$. The respiratory rate was significantly lower among males as compared to their female counterparts $(56.09 \pm 0.58$ and $59.94 \pm 0.45$ breaths per minute respectively). In the same vein, female had the highest beats per minute for pulse rate while the males had the lowest with mean value of ( $77.92 \pm$ 0.46 vs $74.67 \pm 0.39$ beats. Female West African Dwarf sheep were thermally stressed than their male counterparts. This is in agreement with the finding of Butswat et a l.(2000) who reported that female Yankassa, Uda and Balami breeds had significantly higher rectal temperature respiratory rate and pulse rate than their male counterparts.

As shown in Table 1, the mean rectal temperature recorded during late dry season (LDS) was significantly higher than the value recorded for the early rainy season (ERS) $\left(38.93 \pm 0.01^{\circ} \mathrm{C}\right.$ vs $38.60 \pm$ $0.02^{\circ} \mathrm{C}$ ) on the same animals. Higher rectal temperature observed in late dry season might be due to high ambient temperature and relative humidity associated with this season which could exceeds the comfort zone of the animals thereby resulting in imbalance in the heat energy produced and heat energy dissipated. Similar result was observed for respiratory rate. The higher mean value of $65.17 \pm 0.63$ breaths per minute was observed during late dry season and the lowest mean value of $50.87 \pm 0.54$ breaths per minute was recorded during early rainy season $(\mathrm{P}<0.01)$. The mean value for early rainy season $(71.73 \pm 0.03$ beats per minute) was significantly lower than that for the late dry season $(80.86 \pm$ 0.50 beats per minute)

Seasonal variations also had significant effect $(\mathrm{P}<0.01)$ on heat index. The index value obtained for the late dry season was higher than that obtained for early rainy season $(1.64 \pm 0.02$ and $1.59 \pm 0.17)$ respectively. Late dry season was marked with very high ambient temperature and relative humidity. The lower rectal temperature, respiratory rate, pulse rate and heat stress index in the wet season might be as a result of lower ambient temperature and better nutrition status of the animals due to availability of pasture during wet season. The hot climatic condition imposed stress on the animals. The result was in agreement with the report of Shinde et al. (2002) that higher respiratory rate, heat rate and rectal temperature were recorded in monsoon and summer than in winter for goats on the semi-arid range in India. Oladimeji et al. (1996) also reported significant differences in rectal temperature, respiratory rate and pulse rate during the hot dry season over cold dry season (hamattan season) among Yankasa sheep Interaction effect of coat and sex was significant on rectal temperature and heat stress index as shown in Table 2 above .Badger male is well adapted to hot environment than black female. Interaction effect of coat colour and sex was not significant on respiratory rate and pulse rate. Interaction effect of coat colour and season, interaction effect of sex and season as well as the three way interaction of coat colour season and sex were not significant on the physiological parameters.

Blood Parameters. 
Table 2: Least square means for phys

iological parameters as influenced by interaction effect of coat colour and sex

\begin{tabular}{|c|c|c|c|c|c|}
\hline \multirow{3}{*}{$\begin{array}{l}\text { Coat colour } \\
\text { Black }\end{array}$} & \multirow{3}{*}{$\begin{array}{c}\text { Sex } \\
\text { Female } \\
\text { Male }\end{array}$} & \multicolumn{2}{|l|}{ Rectal temp $\left({ }^{\circ} \mathrm{C}\right)$} & \multicolumn{2}{|l|}{ Heat stress Index } \\
\hline & & $39.02 \pm 0.04$ & a & $1.70 \pm 0.01$ & $\mathrm{a}$ \\
\hline & & $38.82 \pm 0.03$ & b & $1.69 \pm 0.01$ & $\mathrm{~b}$ \\
\hline $\begin{array}{l}\text { Brown with } \\
\text { extensive white }\end{array}$ & Female & $38.77 \pm 0.03$ & c & $1.66 \pm 0.00$ & $\mathrm{c}$ \\
\hline Brown mouflon & Male & $38.62 \pm 0.03$ & $\mathrm{~cd}$ & $1.64 \pm 0.01$ & $\mathrm{c}$ \\
\hline \multirow{2}{*}{ Badger face } & Female & $38.68 \pm 0.03$ & $\mathrm{c}$ & $1.49 \pm 0.01$ & d \\
\hline & Male & $38.48 \pm 0.02$ & d & $1.46 \pm 0.01$ & d \\
\hline \multirow{2}{*}{$\begin{array}{l}\text { Black with } \\
\text { extensive white }\end{array}$} & Female & $38.87 \pm 0.02$ & b & $1.65 \pm 0.08$ & c \\
\hline & Male & $38.84 \pm 0.02$ & b & $1.64 \pm 0.01$ & $\mathrm{c}$ \\
\hline
\end{tabular}

Means in the same column with the different superscripts are significantly different $(\mathrm{P}<0.05)$

\begin{tabular}{|c|c|c|c|c|c|c|c|c|c|}
\hline Coat colour & & \multicolumn{2}{|c|}{$\mathrm{RBC}(\mathrm{mil} / \mathrm{mm}$} & WBC(no/mm & $\left.{ }^{3}\right)$ & \multicolumn{2}{|l|}{$\mathrm{Na}^{+}(\mathrm{mmol} / \mathrm{L})$} & \multicolumn{2}{|l|}{$\mathrm{K}^{+}(\mathrm{mmol} / \mathrm{L})$} \\
\hline Black & $25.75 \pm 0.65$ & $3.25 \pm 0.13$ & a & $6033.23 \pm 41.44$ & a & $81.00 \pm 1.26$ & d & $2.16 \pm 0.04$ & d \\
\hline $\begin{array}{l}\text { Brown with } \\
\text { white }\end{array}$ & $25.38 \pm 0.49$ & $2.92 \pm 0.12$ & b & $6366.67 \pm 95.45$ & $\mathrm{~b}$ & $86.33 \pm 3.27$ & $\mathrm{c}$ & $2.53 \pm 0.05$ & $\mathrm{~b}$ \\
\hline $\begin{array}{l}\text { Brown } \\
\text { mouflon }\end{array}$ & $25.00 \pm 1.06$ & $2.98 \pm 0.12$ & b & $6400.23 \pm 51.64$ & $\mathrm{~b}$ & $91.00 \pm 4.74$ & b & $2.58 \pm 0.04$ & $\mathrm{~b}$ \\
\hline Badger face & $24.92 \pm 0.54$ & $2.55 \pm 0.04$ & c & $6550.00 \pm 60.92$ & $\mathrm{a}$ & $104.33 \pm 2.75$ & a & $2.71 \pm 0.04$ & a \\
\hline $\begin{array}{l}\text { Black with } \\
\text { white } \\
\text { Season }\end{array}$ & $24.83 \pm 2.17$ & $3.02 \pm 0.15$ & b & $6200.00 \pm 65.13$ & $\mathrm{c}$ & $89.92 \pm 1.66$ & $\mathrm{~b}$ & $2.31 \pm 0.04$ & $\mathrm{c}$ \\
\hline $\begin{array}{l}\text { Late dry } \\
\text { season }\end{array}$ & $24.12 \pm 0.39$ & $3.25 \pm 0.08$ & a & $6166.67 \pm 47.65$ & $\mathrm{~b}$ & $84.17 \pm 2.34$ & & $2.36 \pm 0.65$ & $\mathrm{~b}$ \\
\hline $\begin{array}{l}\text { Early rainy } \\
\text { season } \\
\text { Sex }\end{array}$ & $25.71 \pm 0.41$ & $2.63 \pm 0.04$ & b & $6416.67 \pm 50.96$ & a & $97.19 \pm 1.46$ & & $2.56 \pm 0.19$ & $\mathrm{a}$ \\
\hline Female & $25.04 \pm 0.43$ & $2.92 \pm 0.09$ & a & $6316.67 \pm 56.35$ & a & $89.54 \pm 2.22$ & $\mathrm{~b}$ & $2.38 \pm 0.04$ & $\mathrm{~b}$ \\
\hline Male & $25.29 \pm 0.40$ & $2.97 \pm 0.09$ & a & $6266.67 \pm 54.72$ & a & $92.42 \pm 2.42$ & a & $2.49 \pm 0.04$ & a \\
\hline
\end{tabular}

Means in the same column with the different superscripts are significantly different $(\mathrm{P}<0.05)$ for coat colour, season and sex

The least square means of packed cell volume (PCV), red blood cell count(RBC), white blood cell count WBC, sodium concentration $\left(\mathrm{Na}^{+}\right)$and potassium concentration $\left(\mathrm{K}^{+}\right)$as affected by coat colour, season and sex are shown on Table 3

Coat colour had significant effect $(\mathrm{P}<0.01)$ on the red blood cell count $(\mathrm{RBC})$. The $\mathrm{RBC}$ values ranged from $2.55 \pm 0.04$ to $3.25 \pm 0.13 \mathrm{mil} / \mathrm{mm} 3$. The Black coat (aaB-SS) had the highest red blood cell count while the badger face had the least value. The differences in the mean value of RBC among brown mouflon (Aabbss), brown with extensive white markings (aabbss) and black with extensive white markings (aaB-ss) were however not significant $(\mathrm{P}>0.05)$. The RBC count was significantly affected by coat colour when the ambient temperature and relative humidity was not comfortable for West African Dwarf sheep. Black coat (aaB ss) type had the highest red blood cell count as a result of high heat burden on black animals. Heat stress increased the number of red blood 
cell count in black sheep. This could be as a result of physiological need for increase in hemoglobin to cope with oxygen circulation during panting of heat stressed animals. This increase in the red blood cell count as a result of heat stress conformed to the findings of Borges et al. (2003) who reported increase in the quantity of red blood cell with heat stress. The white blood cell count (WBC) was also highly significantly $(\mathrm{P}<0.01)$ affected by coat colour. Badger face coat coloured sheep had the highest count of $6550.00 \pm 60.92 \mathrm{no} / \mathrm{mm}^{3}$. The black coat had the least value of WBC of $6033.32 \pm 41.44 \mathrm{no} / \mathrm{mm}^{3}$. The mean WBC value for Black with extensive white markings (aaB-ss) was significantly lower than brown with extensive white markings (aabbss) $(6200.00 \pm 65.13$ and $6366.67 \pm 95.45 \mathrm{no} / \mathrm{mm}^{3}$ respectively). White blood cell count is lower in heat stress animals. This is line with the report of Borges et al. (2003) that heat stress reduces the quantity of white blood cells in animals. Adedeji (2009) also reported that black goats had significantly lower white blood cell count than brown with white marking goats. However, Festus et al. (2005) did not observe any effect of coat colour genotype on white blood count of crossbred pigs. There was no significant difference in the mean value of brown with extensive white markings $\left(6366.67 \pm 95.45 \mathrm{no} / \mathrm{mm}^{3}\right)$ when compared with brown mouflon $\left(6400.00 \pm 51.64 \mathrm{no} / \mathrm{mm}^{3}\right)$

Coat colour also significantly $(\mathrm{p}<0.01)$ influenced the plasma sodium concentration $\left(\mathrm{Na}^{+}\right)$. The mean $\mathrm{Na}^{+}$value ranged between $81.00 \pm 1.26$ and $104.33 \pm 2.75 \mathrm{mmol} / \mathrm{L}$. Badger face (Ab$\mathrm{Bb}$ ss) had the highest value while solid black (aaB-SS) had the least. The mean value for blown mouflon $91.00 \pm 4.74$ $\mathrm{mmol} / \mathrm{L}$ was significantly higher than brown with extensive white markings (aabbss) $85.33 \pm 3.27 \mathrm{mmolL}$. There was no significant difference in the mean values for black with extensive white markings and brown mouflon (Aabbss) $(89.92 \pm 1.66$ and $91.00 \pm 4.74 \mathrm{mmol} / \mathrm{L}$ respectively

The plasma potassium concentration was also significantly $(\mathrm{p}<0.01)$ affected by coat colour. The mean value ranged from $2.16 \pm 0.04 \mathrm{mmol} / \mathrm{L}$ to $2.71 \pm 0.07 \mathrm{mmol} / \mathrm{L}$ with the badger face having the highest value while, the black coat coloured sheep had the least value. There was no significant difference in the mean values for brown mouflon $(2.58 \pm 0.05 \mathrm{~mm} / \mathrm{L})$ and brown with extensive white markings (aabbss) $(2.31 \pm 0.04 \mathrm{mmol} / \mathrm{L}$ and $2.53 \pm 0.05 \mathrm{mmol} / \mathrm{L}$ respectively).

Animals with dark pigmentation had a lower value of sodium and potassium concentration as a result of high net solar radiation impinging on the skin of dark coloured animals. Heat stress reduced sodium and potassium concentration. The decrease in plasma electrolyte especially the cation with increase in body temperature was in agreement with the report of Borges et al. (2003) but contradict the report of Srikandakumar and Johnson (2004) that heat stress increased plasma potassium in Holstein and Jersey cows but lowered the concentration in Australian milking zebu. The plasma electrolytes studied were significantly $(\mathrm{P}<0.05)$ affected by sex. Males had higher sodium concentration of $92.42 \pm 2.42$ when compared to their female counterparts with the $89.54 \pm 2.2$. The potassium concentration $\left(\mathrm{K}^{+}\right)$for female $(2.38 \pm 0.06)$ was significantly $(\mathrm{P}<0.05)$ lower than the mean value for male (2.49 \pm 0.05$)$. Sex did not influence the mean values of the PCV percentage. Similar result was obtained for the red blood cell count as the difference in the 
mean values for female $2.92 \pm 0.09 \mathrm{ml} / 1$ was not significantly different form the mean values for males $2.97 \pm 0.09$.

The red blood cell was highly significantly $(\mathrm{P}<0.01)$ affected by season. Higher mean value of $3.25 \pm$ $0.08 \mathrm{mil} / \mathrm{mm}^{3}$ was recorded during late dry season while a lower value of $2.63 \pm 0.04 \mathrm{mil} / \mathrm{mm} 3$ was recorded for early rainy season. WBC count was significantly $(\mathrm{P}<0.05)$ affected by season as shown in Table 3 . The mean value of $6416.67 \pm 50.96 \mathrm{no} / \mathrm{mm}^{3}$ for early rainy season was significantly higher that $6166.67 \pm 47.65 \mathrm{no} / \mathrm{mm} 3$ for late dry season. Season also significantly $(\mathrm{P}<0.05)$ affected the sodium concentration. A lower value of $84.17 \pm$ $2.34 \mathrm{mmol} / 1$ was recorded during late dry season compared to the value of 97.19 \pm 1.46 recorded during the early rainy season on the same animals. Similar result was obtained for potassium concentration as the mean value of $2.56 \pm$ $0.19 \mathrm{mmol} / \mathrm{L}$ recorded during early rainy season was significantly $(\mathrm{P}<0.05)$ higher than $2.36 \pm 0.65 \mathrm{mmol} / \mathrm{L}$ recorded during late dry season on the same animals. Lower levels of sodium and potassium concentration during the hot weather might be due to loss of $\mathrm{Na}$ ions in sweat under the tropical environmental condition .The lower levels of sodium and potassium concentration in this study during late dry season was in agreement with the observation of Adedeji (2009) who reported that West African Dwarf goats had significantly lower values of $\mathrm{Na}$ and $\mathrm{K}$ ions during hot season compared to rainy season.

The interraction effect of coat colour and sex,coat colour and season, sex and season as well as the three way interraction of caot colour, sex and season were not significant on all the blood parameters measured .

\section{Conclusion}

The effect of coat on heat stress was significant. Animals with dark pigmentation were more prone to heat stress than animals with light pigmentation. Black sheep and others with dark pigmentation would be provided with shade and allowed to graze only in early hours of the morning and later in evenings to avoid direct exposure to sunshine during hot season against in area with very high ambient temperature.

\section{References}

Adalsteinsson, S., Sponemberg, D.P. Alexieva, S.and Russell, A.J.F.1994. Inheritance of goat coat colours. Journals of Heredity, 85,267272

Adedeji T.A 2009. Pleiotropic effect of coat colour and wattle genes on the adaptive potentials of West African Dwarf goats. Ph.D Thesis, University of Agriculture, Abeokuta. $P p 88$

Altan, O., Pabuccuglu, A., Konyaliodu,S. and Bayracktar, I.T.2003. Effect on heat stress of lipid peroxidation and some stress parameters in broilers. British Poultry Science, 44:545 550

Borges, S.A., Ariki, J., Hooges, D.M and Cummings, K.R 2003. Dietary electrolyte balance for broiler chikens exposed to thermoneutral and heat stress environments. Poultry Science, 48:428:435

Butswat, I.S., Mbap.S.T. and Ayibantoye, G.A 2000. Heat tolerance of sheep in Bauchi, Nigeria Trop. Agric .(Trinidad) 77 (4):265 268

Chytil, M.A. 2002. Physiological response of slick versus normal 
haired Holstein and Senepol crossbred cattle in Florida. Masters of Science Thesis. University of Florida. pp108

Edington, G.M. and Gilles, H.M 1981. Pathology of Animal Diseases in the Tropics Second Edition. Edward Arnold Publisher Ltd pp 85

Festus, L., Zsolnai, A and Komlosi I. 2005. Influence of porcine coat colour genotype on haematological parameters, piglet birth weight and pre-weaning body weight gain. Journal Animal Breeding and Genetics 122:127-130

Gwatibaya, S.Svotia, E. and Jambwa, D.2007. Potential effects and management options for heat stress in dairy cows in Zimbabwe: A review, Electronic Journal of Environmental, Agricultural and Food Chemistry. 6:2066 2074

Hansen, P.J. 2004. Physiological and cellular adaptation of zebu cattle to thermal stress, Animal Reproduction Science, 82:349 360

Marai, I., El-Darawany, A., Fadiel, A.and Abdel Hafez, M. 2003. Physiological traits as affected by heat stress in sheep: A review, Small Ruminant Research.71:1-12.

Oladimeji, B.S., Osinowo, O.A., Alawa, J.P and Hambolu J.O 1996 .Estimation of average values of pulse rate, respiratory rate and rectal temperature and development of heat stress index for adult Yankasa sheep. Bulletin of Animal Health and Production 44:105-107.

Ozoje, M.O. 1998. Coat colour, gene in West African Dwarf sheep and goats : A theoretical appraisal . In . Proceeding of $16^{\text {th }}$ World Congress on Genetics and Applied Livestock Production, Vol 26 pp 53-56

SAS 2005. Statistical Analysis System .
SAS Stat. Version 10. SAS Institute Inc. Gary NC 27513, U.S.A.

Shinde, A.K., Bhatta, R., Sanliyan, S.K. and Verma D.L. 2002. Effect of season on thermoregulatory responses and energy expenditure of goat on Semi arid range in India. The Journal of Agricultural Science, 139:87-93.

Silanikove, N.2000. The physiological basis of adaptation of goats to scarcity of food and water in harsh environments, Small Ruminants Research, 35:181-193

Srikandakumar, A. 2003. Effect of heat stress on respiratory rate, rectal temperature and blood chemistry in Omani and Australian Merino sheep. Small Ruminant Research, 49:193

Srikandakumar, A. and Johnson E.H. 2004. Effect of heat stress on milk production, rectal temperature, respiratory rate and blood chemistry in Holstein, Jersey and Australian Milking Zebu cows. Tropical Animal Health and Production. 36 (7)):685 692 . 